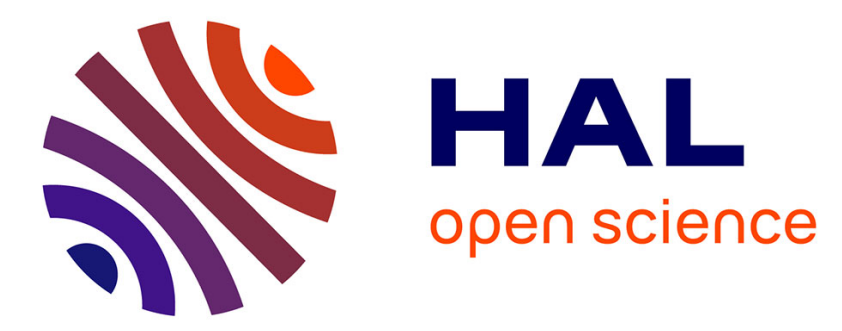

\title{
Risk of Fire blight infection associated with pruning of pear trees
}

P. Lecomte

\section{To cite this version:}

P. Lecomte. Risk of Fire blight infection associated with pruning of pear trees. Acta Horticulturae, 1990, 273, pp.83-89. hal-01600326

\section{HAL Id: hal-01600326 \\ https://hal.science/hal-01600326}

Submitted on 1 Jun 2020

HAL is a multi-disciplinary open access archive for the deposit and dissemination of scientific research documents, whether they are published or not. The documents may come from teaching and research institutions in France or abroad, or from public or private research centers.
L'archive ouverte pluridisciplinaire HAL, est destinée au dépôt et à la diffusion de documents scientifiques de niveau recherche, publiés ou non, émanant des établissements d'enseignement et de recherche français ou étrangers, des laboratoires publics ou privés.

\section{다(1) (2)}

Distributed under a Creative Commons Attribution - ShareAlikel 4.0 International 
RISK OF FIRE BLIGHT INFECTION ASSOCIATED WITH PRUNING OF PEAR TREES

\title{
P. Lecomte
}

I.N.R.A. - Station de Pathologie Végétale

Route de Saint Clément

BEAUCOUZE - 49000 ANGERS

Present adress : Lycée Agricole de DAX OEYRELUY, BP 1, HEUGAS, 40180 DAX, FRANCE

\begin{abstract}
$\underline{\text { Abstract }}$
Infection risks of fire blight on branches pruned with contaminated shears were investigated. Experiments in the field with "naturally" infected shears showed a nil infection occurrence during dormant period and variable results during the growing season. In order to determine more precisely infection risks during dormant period, weekly artificial inoculations were done by dipping the shears in a bacterial suspension. Different cultivars, two bacterial strairs, CFBP 1430 and CFBP 2045, were used. Shoots showing infections after pruning were recorded in late April.
\end{abstract}

Results indicated that as far as prevention of fire blight spreading is concerned, the best period to prune trees is full dormant period (before March, in Dax area).

\section{Introduction}

After the outbreak of fire blight in the South West of France, growers needed more informations about risks of infection due to pruning. Furthermore, they needed to use an effective and convenient method to disinfect pruning tools. In order to study these two aspects of the relationships between fire blight and pruning, several experiments have been conducted in the laboratory or in the orchard in DAX experimental field, since the beginning of the AGRIMED programme in 1979. Experiments about assessment of infection risks are reported here.

The role of contaminated pruning tools is considered to be very important in the dissemination of the fire blight pathogen (BEER, VAN DER ZWET \& KEIL,1979) and serious infections have been observed in orchards or in nursery blocks after pruning branches with shears suspected to be contaminated (WAITE \& SMITH, 1906). The need for an effective pruning tools disinfection incited many experiments (DECKERS \& $a l, 1987$, KLEINHEMPEL \& $a l, 1987$ ). 
If bacterial dissemination by pruning is long suspected, not many experimental proofs exist and very few investigations were done to study the spreading conditions which can facilitate this dissemination. The following work was undertaken to understand more about infection probabilities with pruning and to know if some factors such as varieties, bacterial strains, period of the year, may play a role.

The second aspect of our work, disinfection of pruning tools, has been more often studied by others. We have found that dipping or spraying the shears with a chlorine solution were the more effective methods. Complete results of these particular experiments will be published elsewhere.

\section{Infection risks associated with pruning}

\subsection{Natural contamination of pruning shears}

In autumn 1980, a preliminary testing was done to check the bacterial contamination of shears after pruning a blighted branch. Fresh and active symptoms were chosen on young shoots of Passe-Crassane pear trees. After cutting through fresh lesions, the shears blades were washed and bacterial population was evaluated in the laboratory. All the washings allowed the isolation of the bacteria : from $10^{2}$ to $2.10^{4}$ cells were found on shear blades.

We have then tried "natural" conditions of infection. The method used was simulating cultural practice : symptoms were collected and healthy shoots were pruned with a shear contaminated by cutting in these active lesions. From 50 to 160 shoots were then pruned on healthy trees with this shear. Such experiments were repeated in winter $(1980,1981,1982)$ or in summer $(1987,1988)$ on Passe-Crassane pear trees in the experimental orchard.

We have never observed any development of the disease in spring (or later on) from the winter pruned shoots. On the contrary, results obtained with the summer period pruning were positive, although variable(table 1). In 1988, there was a three days rainy period immediately after pruning, while in 1987, a dry period of at least one week followed inoculation. These weather conditions can partly explain the differences between the two years.

This type of experiment was not often repeated, because it was very difficult to find enough fresh lesions available during the whole year. It should be necessary to induce fresh symptoms by regular inoculations on susceptible and receptive plant material. Artificial techniques were therefore prefered to go further. 
/ experimental ling conditions undertaken to know if some role.

sen more often with a chlorine ese particular

the bacterial ive symptoms dtting through as evaluated in : from $10^{2}$ to

hod used was ts were pruned to 160 shoots se repeated in le pear trees in

g (or later on) $h$ the summer re was a three of at least one the differences

sry difficult to e necessary to sceptive plant

\section{2. Artificial contamination of pruning shears during dormant season}

- Material and methods

A standard pruning shear dipped in a bacterial suspension $\left(10^{9} \mathrm{cfu} / \mathrm{ml}\right)$ was used in the following experiments. Contamination was tested by pruning 20 to 30 one year-old pear shoots at regular intervals, (once a week, as far as possible). From 1983 to 1987, during dormant season, five experiments were carried out on young pear plots in the field.

Three well known cultivars, previously tested for fire blight susceptibility (THIBAULT et al, 1987), Passe-Crassane, William's and Beurré Hardy, and two strains of Erwinia amylovora, CFBP 2045 and CFBP 1430, were used and compared in some experiments..

The number of shoots showing progressive infections was recorded in late April, after bloom period.

Main features of each experiment are reported on table 2.

- Results

They are summarized on figures 1 to 4 . Disease rating is expressed as a percentage of infections: number of infections/number of inoculated shoots.

Figure 1 presents results of experiments 1, 2, 3 carried out on Passe-Crassane which is a very susceptible cultivar to fire blight. A variability between years is observed: in 1983 and 1984 the infection level increased, not always regularly, in coming spring, during bud burst; in 1985 high frequencies of infection are noted earlier.

Figure 2 presents the result of experiment 4 . It shows a comparison of the infection levels on two cultivars which are known to be moderately susceptible. Curves are not different, and disease frequency obviously increased in late March in both cases.

The fifth experiment lasted longer and was more complete than the previous ones. Two strains and two cultivars :

- on Passe-Crassane (figure 3), infections do occur during all the winter period, especially with the strain 1430 , which is knowato be more aggressive than 2045 ,

- on William's (figure 4), the infection mainly appeared in coming spring, and is again more frequent with 1430 than with 2045. 


\section{Discussion and Conclusion}

Infection risks with winter pruning under practical conditions have not been clearly demonstrated here. Nevertheless bacteria were isolated on shear blades after pruning fresh lesions. Amount of bacterial cells found could be too low to allow an effective spread. Further studies are necessary to gather more informations about the level of practical risks linked with pruning during the winter period.

Artificial contamination of pruning shears provided higher infection levels than the 'natural' method. Infection risks with pruning seemed to depend on several factors ; among them : susceptibility of the varieties, aggressiveness of the strain and physiological stage of the plant. Influence of the weather is rather difficult to determine but certainly important. The influence of climate could provide an explanation for the observed variability between years, but other environmental factors are likely to be involved.

In an area where disease has been recorded or suspected the previous year(s), full dormant period seems to be the pruning period to be recommended, to limit risks of spreading the disease. Nevertheless, very susceptible cultivars, like Passe-Crassane seem to be permanently receptive to infection at least under our experimental conditions.

\section{Acknowledgements}

Special thanks are due to J.P. PAULIN for fruitful discussions and to A. GOSSET for her precious technical assistance. The author is also very grateful to his colleagues at INRA-ANGERS for their help during the preparation of the manuscript.

\section{References}

Beer, S.V., 1979. Fire blight inoculum: sources and dissemination. EPPO Bull. 9(1): 13-25.

Deckers, T., Ieven, B. and Porreye, W., 1987. La désinfection des outils de taille afin d'éviter la dispersion du feu bactérien dans les vergers. Le Fruit Belge, $\mathrm{N}^{\circ} 420$ : 307-310.

Kleinhempel, H., Nachtigall, M., Ficke, W. and Ehrig, F., 1987. Disinfection of pruning shears for the prevention of the fire blight. Acta Horticulturae, $217: 211$ 218.

Thibault, B., Lecomte, P., Hermann, L., Belouin, A., 1987. Assessment of the susceptibility to Erwinia amylovora of 90 varieties or selections of pear. Acta Horticulturae, $217: 305-310$.

Waite, M.B., and Smith, R.E., 1906. Pear blight - it's introduction, cause and treatment, and work of eradication. Calif. State Hort. Com. Spec. Rpt. 1906, 27pp.

Zwet, T., Van Der, and Keil, H.L., 1979. Fire blight, a bacterial disease of Rosaceous plants. U.S.D.A. Agriculture Handbook $N^{\circ} 510,200$ p. 
Table 1 - Trials with 'naturally' contaminated shears in Summer 1987 \& 1988.

been clearly ifter pruning an effective the level of

vels than the ral factors ; : strain and to determine ation for the likely to be

year(s), full imit risks of se-Crassane sperimental

\section{GOSSET} ; colleagues

Bull. 9(1): e taille afin $e, N^{\circ} 420$ : nfection of $217: 211-$

lent of the pear. Acta cause and Rpt. 1906, Rosaceous

\begin{tabular}{|l|rrrrrrrr|r|}
\hline & \multicolumn{1}{|c|}{ Inoc. series } & $\begin{array}{c}\text { Average } \\
\%\end{array}$ \\
\hline & $1^{*}$ & 2 & 3 & 4 & 5 & 6 & 7 & 8 & \\
July 29, 1987. & $0^{* *}$ & 5 & 0 & 5 & 0 & 5 & 0 & 0 & 2 \\
July 13, 1988. & 10 & 25 & 30 & 30 & 10 & 15 & 5 & 10 & 17 \\
\hline
\end{tabular}

* 20 shoots pruned per serie

** \% of infected shoots

Table 2 - Conditions of experiments (artificially contaminated shears)

\begin{tabular}{|cllll|}
\hline Experiments & Year & Dates & Cultivar & Strain \\
\hline 1 & 1983 & $26 / 1$ to $11 / 4$ & P. Crassane & 2045 \\
2 & 1984 & $17 / 1$ to $02 / 4$ & P. Crassane & 2045 \\
3 & 1985 & $03 / 1$ to $13 / 2$ & P. Crassane & 2045 \\
4 & 1986 & $24 / 1$ to $21 / 3$ & B. Hardy \& William's & 2045 \\
5 & 1987 & $26 / 11$ to 31/3 & P. Crassane \& William's & 2045 \& 1430 \\
\hline
\end{tabular}



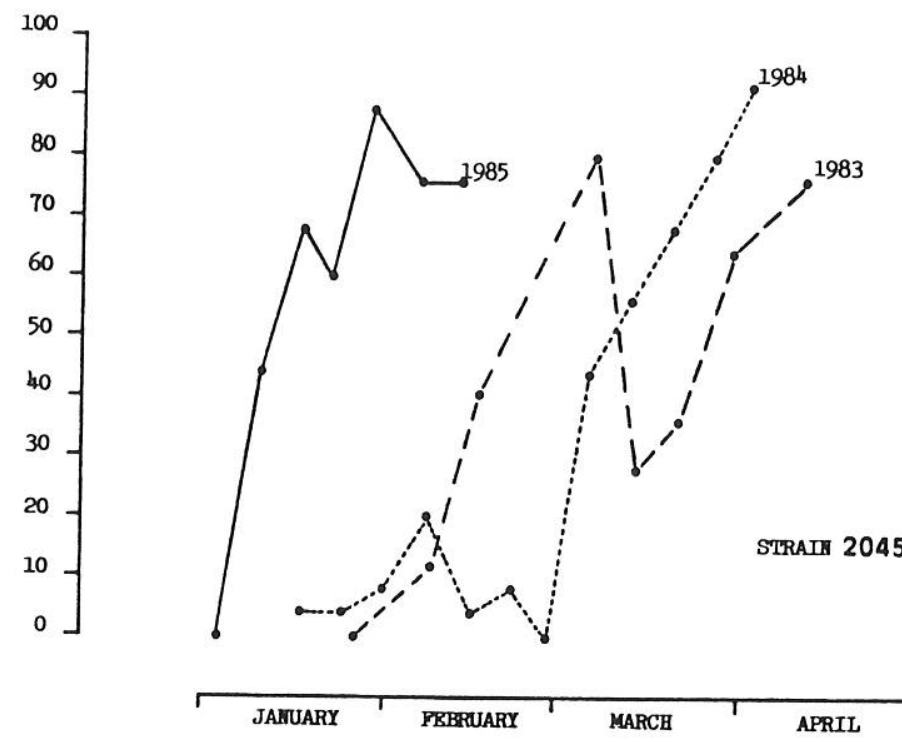

FIGURR 1 - PERCEITTAGB OF I IFBCTIOIS OI PASSB-CRASSAIIB BXPKRTMEITT 1 TO 3, HINTKR 1983,1984,1985

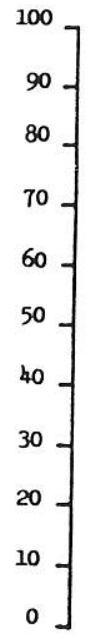

- CV HILLTAM'S

- CV B. HARDY

STRAII 2045

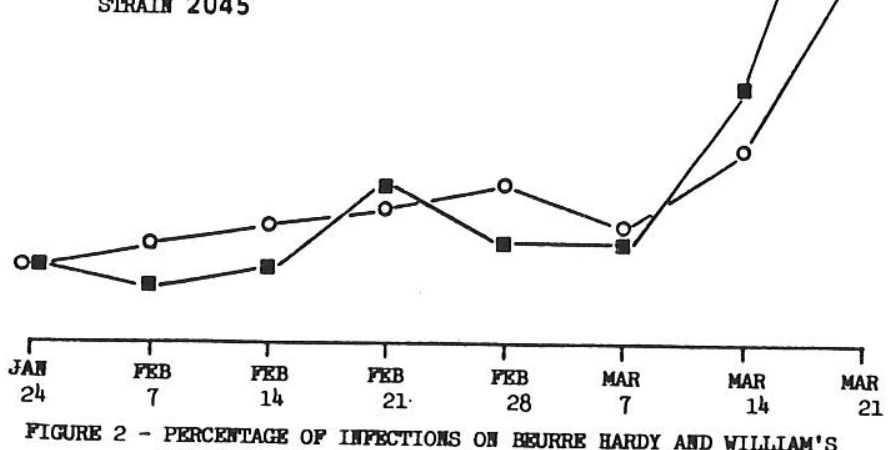
EXPPRDNITITT 4, WITIKRR 1986 


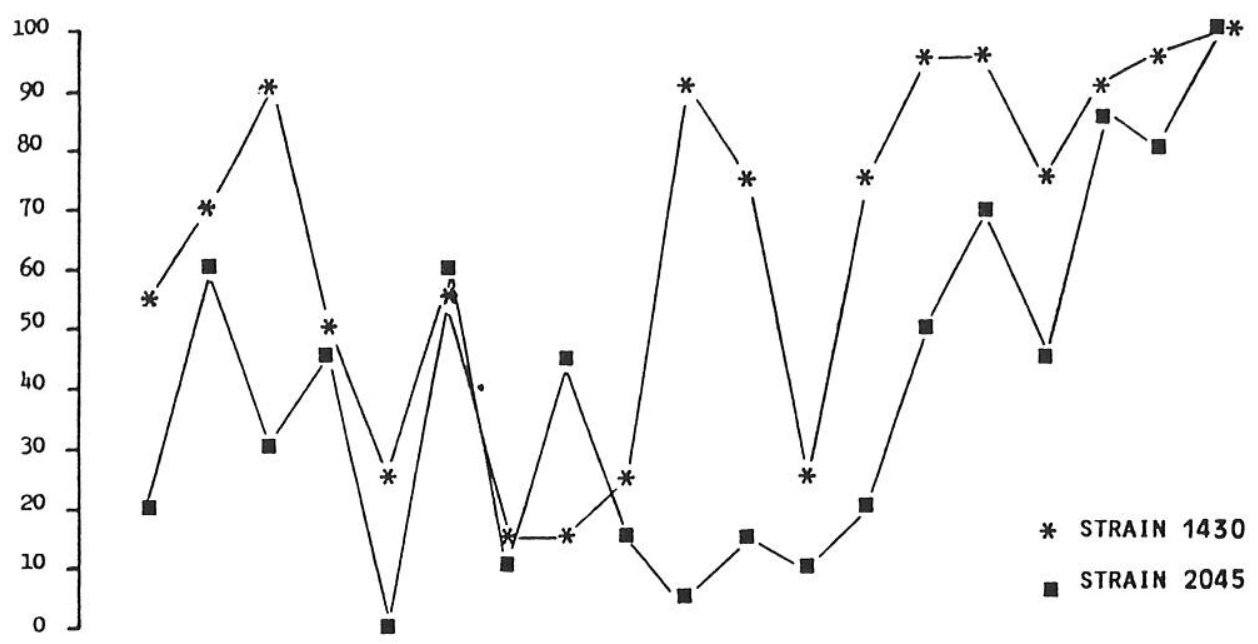

NoV DEC DEC DEC DEC DEC JAN JAN JAN JAK FEB FEB FEB FEB MAR MAR MAR MAR MAR $\begin{array}{lllllllllllllllllll}26 & 2 & 9 & 16 & 23 & 30 & 6 & 13 & 20 & 27 & 3 & 10 & 17 & 24 & 3 & 10 & 17 & 24 & 31\end{array}$ FIGURB 3 - PERCERTAGB OF INFBCTIONS OII PASSB-CRASSAFB - EXPERDMERT 5, 1987

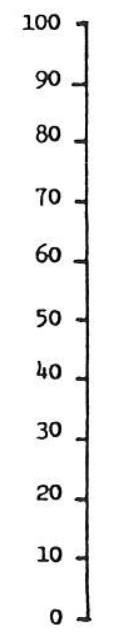

口 SIRAIN 1430

- Strain 2045 